Article

\title{
Investigation of the Pyridinium Ylide-Alkyne Cycloaddition as a Fluorogenic Coupling Reaction
}

\author{
Simon Bonte ${ }^{1}$, Ioana Otilia Ghinea ${ }^{2}$, Rodica Dinica ${ }^{2}$, Isabelle Baussanne ${ }^{1, *}$ and \\ Martine Demeunynck ${ }^{1, *}$ \\ 1 Department of Pharmacochemistry, Université Grenoble Alpes, CNRS, DPM UMR 5063, F-38041 Grenoble, \\ France; simontlse.12@gmail.com \\ 2 Department of Chemistry, Physics and Environment, Faculty of Science and Environment, \\ “Dunarea de Jos” University of Galati, 111 Domneasca Street, 800201 Galati, Romania; \\ otilia.ghinea@gmail.com (I.O.G.); rodicad@yahoo.com (R.D.) \\ * Correspondence: isabelle.baussanne@ujf-grenoble.fr (I.B.); \\ martine.demeunynck@univ-grenoble-alpes.fr (M.D.); Tel.: +33-476-635-314 (M.D.)
}

Academic Editor: Philippe Belmont

Received: 26 January 2016 ; Accepted: 4 March 2016 ; Published: 10 March 2016

\begin{abstract}
The cycloaddition of pyridinium ylides with alkynes was investigated under mild conditions. A series of 13 pyridinium salts was prepared by alkylation of 4-substituted pyridines. Their reactivity with propiolic ester or amide in various reaction conditions (different temperatures, solvents, added bases) was studied, and 11 indolizines, with three points of structural variation, were, thus, isolated and characterized. The highest yields were obtained when electron-withdrawing groups were present on both the pyridinium ylide, generated in situ from the corresponding pyridinium salt, and the alkyne $(\mathrm{X}, \mathrm{Z}=$ ester, amide, $\mathrm{CN}$, carbonyl, etc.). Electron-withdrawing substituents, lowering the acid dissociation constant $(\mathrm{pKa}$ ) of the pyridinium salts, allow the cycloaddition to proceed at $\mathrm{pH} 7.5$ in aqueous buffers at room temperature.
\end{abstract}

Keywords: indolizine; coupling reaction; ylide; dipolar cycloaddition

\section{Introduction}

We have been interested in the indolizine chemistry for several years. Indolizine is a nitrogen-containing bicyclic heterocycle, and its derivatives display interesting biological [1-5] and optical properties [6-13] (fluorescence and circular dichroism [14,15]). Indolizines have been used as biomarkers [16] and in the fluorescent labeling of carbon nanotubes [17] and graphene [18], for instance. Among the main routes of preparation that have been designed, we can cite the metal-catalyzed cyclization of 2-alkynylpyridines [19-25] or 2-pyridine alkynyl carbinols [26-31]. The most common metal-free methodology [2,32,33] involves the 1,3-dipolar cycloaddition of pyridinium ylides with alkynes (Scheme 1) [2,34-39]. The dihydroindolizines thus formed spontaneously, aromatize under air oxidation. This chemistry has been the subject of a large number of publications, focusing, in particular, on the formation and reactivity of the ylides [34,35,40-44] and on the mechanism of the cycloaddition [33]. More recently, improvements in the reaction conditions have been reported, by using oxidant-free cycloaddition to alkenes [32], one-pot [38], microwave-activated [34,35], or biocatalyzed processes [36]. Note that most of the work reported so far in the literature involved $\mathrm{N}$-benzoylmethylpyridinium-derived ylides [45,46]. The purpose of the present work was to explore the potency of the pyridinium ylide-alkyne cycloaddition as a click-type coupling reaction. 


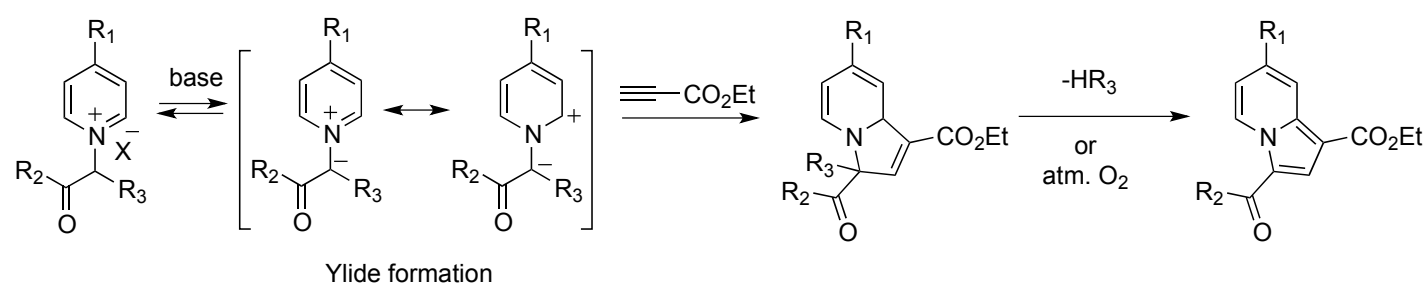

Scheme 1. General mechanism.

The key points to investigate were the effectiveness of this cycloaddition in mild conditions (room temperature, neutral or near neutral conditions), ease of accessibility of the reactants, and their practical pre- or post-functionalization. For all these reasons, we decided to prepare a series of ylide precursors (pyridinium salts) and to compare their reactivity in the presence of alkynes in various conditions. We first aimed to select the best partners for the application as coupling methodology. To achieve this goal, we modified the structure of the ylide precursors: reactive or easily modified substituents were introduced on the pyridinium salts $\left(R_{1}\right.$ group in Scheme 1$)$ and ester or amide groups were used to stabilize the ylide $\left(\mathrm{R}_{2}=\mathrm{RO}\right.$ - or $\mathrm{RNH}$-, in Scheme 1$)$ in place of the benzoyl group usually reported in the literature. The structure optimization of the reactants allowed the cycloaddition to proceed at room temperature in very mild conditions including $\mathrm{pH} 7.5$ aqueous buffers, yielding indolizines with three possible points of functionalization.

\section{Results}

\subsection{Preparation and Characterization of the Pyridinium Salt}

We first prepared a series of 13 pyridinium salts. To keep the symmetry of the starting molecule and to prevent formation of regioisomers after cycloaddition, substituents were only introduced at position 4 of the pyridine ring [37].

The pyridinium salts were obtained by alkylation of the pyridine derivatives with methyl 2-bromoacetate (compounds 1-7), 2-iodoacetophenone derivatives (compounds 8 and 9), or 2-bromo- $\mathrm{N}$-propylacetamide (compound 10) in acetone under ultrasound activation. In the case of alkylation with diethyl 2-iodomalonate to prepare the pyridinium salts containing two carboxylic esters (compounds 11-13, $\mathrm{R}_{3}=\mathrm{CO}_{2} \mathrm{Et}$ ), very low yields were observed under these conditions. The reaction was improved by using the diethyl 2-iodomalonate in large excess. The structures, yields, pKa and ${ }^{1} \mathrm{H}-\mathrm{NMR}$ data are collected in Table 1.

As previously observed [47,48], the electronic nature of the substituent present at position 4 modulates the pKa values, and the pKa variation correlates well with the Hammett constant of the $\mathrm{R}_{1}$ group. The electron-withdrawing groups decrease the $\mathrm{pKa}$ values (compare $4-\mathbf{7}$ versus $\left.\mathbf{1}\right)$. This effect was more pronounced with mesomeric $\left(\mathrm{CN}\right.$ or $\left.\mathrm{COCH}_{3}\right)$ than inductive $\left(\mathrm{CF}_{3}\right)$ withdrawing substituents. The effect of the nature of $\mathrm{R}_{1}$ has been studied [49] and seemed more prominent for the phenacyl analogues [47], however the measurements were made in different conditions (ylides dissolved in methanol). In another study, the deprotonation of pyridinium salts was studied by NMR in DMSO in the presence of a strong base [48]. The authors found that the effect on the deprotonation of the ring substituents was greater than the effect of the methylene substituent.

The proton NMR spectra of 4-substituted pyridinium salts are characterized downfield by two multiplets for $\mathrm{H}-2 / \mathrm{H}-6$ and $\mathrm{H}-3 / \mathrm{H}-5$, the latter being more shielded, and a singlet for the $\mathrm{CH}_{2}$ generally found between 4.4 and $6.6 \mathrm{ppm}$. The correlation between the presence of the electron-withdrawing group $\mathrm{R}_{1}$ and $\mathrm{pKa}$ (deprotonation and ylide formation) is reflected by higher $\delta$ value for the $\mathrm{CH}_{2}$ signal. The integration of this singlet was lower than expected with compounds 4-6 and this signal may also be lacking (see $\mathbf{1 1}$ and 12) probably due to high $\mathrm{H} / \mathrm{D}$ exchange rate in $\mathrm{CD}_{3} \mathrm{OD}$. We observed in the spectrum of the 4-acetylpyridinium salt 6 in $\mathrm{CD}_{3} \mathrm{OD}$, the presence of a second set of shielded signals, not found in DMSO- $d_{6}$, which was attributed to the formation of hemiketal or ketal derivatives 
in this solvent and that increased with time spent in solution (the simulated spectra of the different species were in agreement with the experimental data).

Table 1. Structures, yields, pKa values, and proton NMR data of the pyridinium salts.

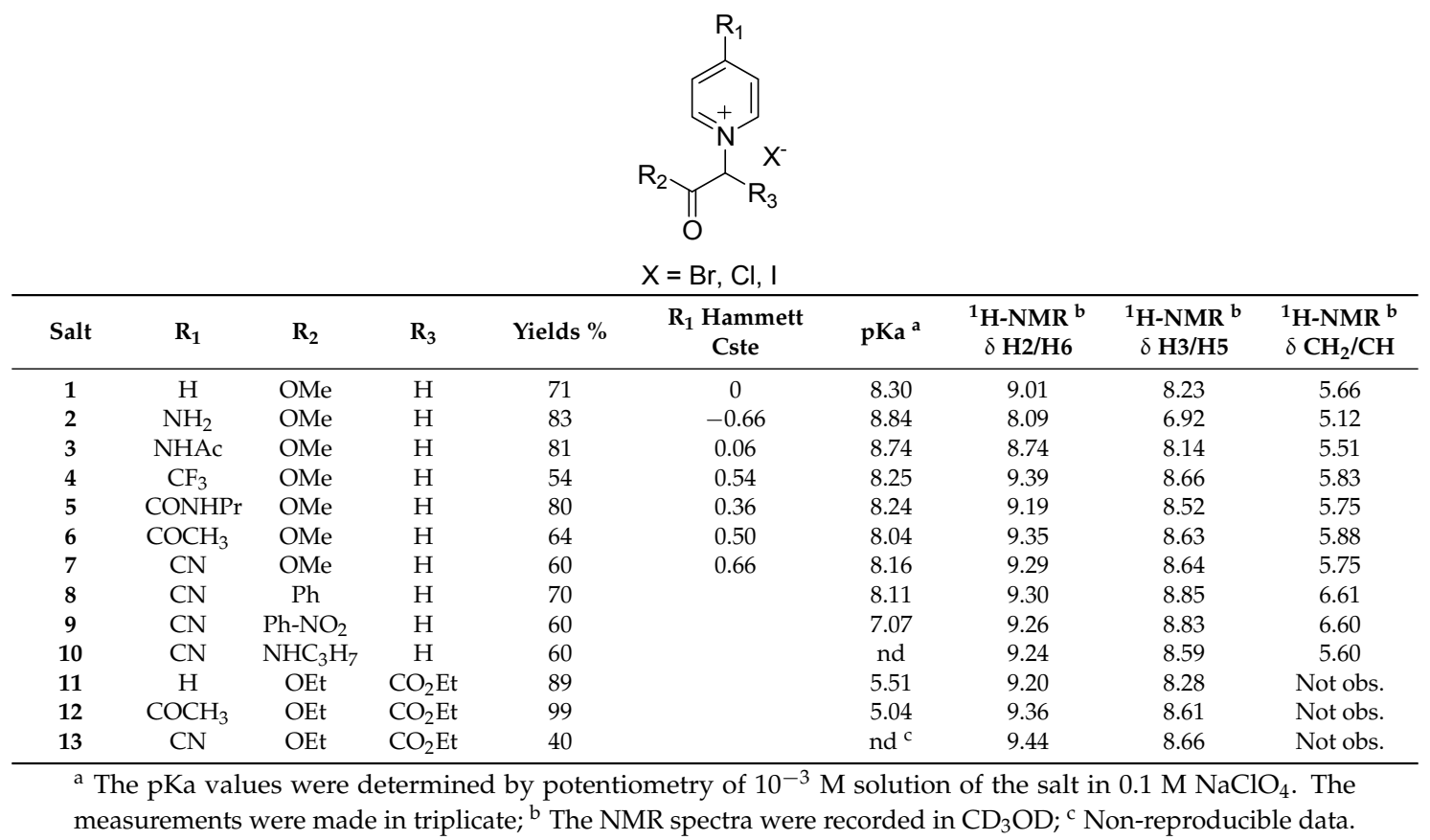

\subsection{Reactivity Studies}

The reactivity of the different salts with alkynes was compared using a reference reaction: methanol was chosen as solvent, ethyl propiolate as dipolarophile, and $\mathrm{K}_{2} \mathrm{CO}_{3}$ for ylide generation. The reaction mixtures were stirred at $25^{\circ} \mathrm{C}$ for $18 \mathrm{~h}$, and the indolizines were isolated. The ease of isolation and purification is an important point for the usefulness of the reaction. Therefore, in the following tables, we give and discuss the yields of isolated indolizines.

As known in the literature, the cycloaddition is fully regioselective, the ethyl and methyl esters being found in positions 1 and 3, respectively, in our study and easily identified.

\subsubsection{Influence of the $R_{1}$ Substituent}

We first studied the importance of the nature of $R_{1}$ on the reactivity (Table 2). Introduction of electron-withdrawing groups on the pyridine ring clearly favored the cycloaddition. Higher yields (77\% and $81 \%$ ) were obtained in the presence of electron-withdrawing mesomeric groups $\left(\mathrm{COCH}_{3}\right.$ or $\mathrm{CN}$, respectively) that efficiently stabilize the negative charge of the ylides by delocalization. In the case of the $\mathrm{CF}_{3}$ substituent (entry 6), the NMR data showed the presence of the desired indolizine 19 and of the corresponding dimethyl carboxylate, formed by trans-esterification of the ethyl ester at position 1 by methanol. To selectively prepare 19, the reaction should be performed in ethanol or in a non-nucleophilic solvent such as DMF (cf. part 2.2.2). Under these mild conditions, the 4-amino or amido-substituted pyridinium salts (entries 2 and 3), which display the lowest Hammett constant, did not react. 
Table 2. Influence of the pyridine substituent $R_{1}$ on the yields of indolizines ${ }^{a}$.

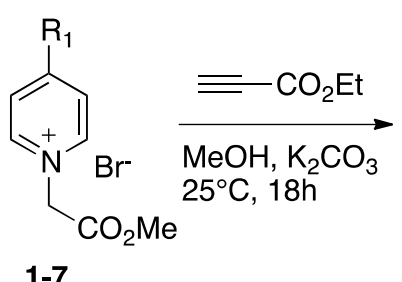<smiles>CCOC(=O)c1cc(C(=O)OCC)n2ccc(Br)cc12</smiles>

\begin{tabular}{cccccc}
\hline Entry & Pyridinium Salt & $\mathbf{R}_{\mathbf{1}}$ & $\begin{array}{c}\text { Hammett } \\
\text { Constant }\end{array}$ & Indolizine & Yield (\%) \\
\hline 1 & $\mathbf{1}$ & $\mathbf{H}$ & 0 & $\mathbf{1 4}$ & 59 \\
2 & $\mathbf{2}$ & $\mathbf{N H}_{\mathbf{2}}$ & -0.66 & $\mathbf{1 5}$ & 0 \\
3 & $\mathbf{3}$ & $\mathrm{NHAc}$ & 0.06 & $\mathbf{1 6}$ & 0 \\
4 & $\mathbf{5}$ & $\mathrm{CONHPr}$ & 0.36 & $\mathbf{1 7}$ & 66 \\
5 & $\mathbf{6}$ & $\mathrm{COCH}_{3}$ & 0.50 & $\mathbf{1 8}$ & 77 \\
6 & $\mathbf{4}$ & $\mathrm{CF}_{3}$ & 0.54 & $\mathbf{1 9}$ & $55^{\mathrm{b}}$ \\
7 & $\mathbf{7}$ & $\mathbf{C N}$ & 0.66 & $\mathbf{2 0}$ & 81 \\
\hline
\end{tabular}

a The pyridinium salts (1 eq.) and ethyl propiolate (1.5 eq.) were dissolved in $\mathrm{MeOH} . \mathrm{K}_{2} \mathrm{CO}_{3}$ (1 eq.) was then added to generate the ylides and the resulting solutions were stirred $18 \mathrm{~h}$ at room temperature. ${ }^{\mathrm{b}}$ Mixtures of 19 and of the corresponding 1,3-dimethyl carboxylate analogue were obtained in a non-reproducible ratio.

From these experiments, compounds $\mathbf{6}$ and $\mathbf{7}$ were selected for further studies.

\subsubsection{Influence of the Solvent and of the Nature of the Added Base}

To evaluate the importance of the solvent on the cycloaddition efficiency, the reactions were performed in parallel in DMF, a polar non-nucleophilic solvent, and methanol. Three bases, $\mathrm{NH}_{4} \mathrm{OH}$, $\mathrm{NEt}_{3}$, and $\mathrm{K}_{2} \mathrm{CO}_{3}$ were also tested. The data are collected in Table 3.

Table 3. Influence of the nature of the solvent and of the base on the yields of indolizines $\mathbf{1 8}$ and $\mathbf{2 0}$ from pyridinium salts 6 and 7 .

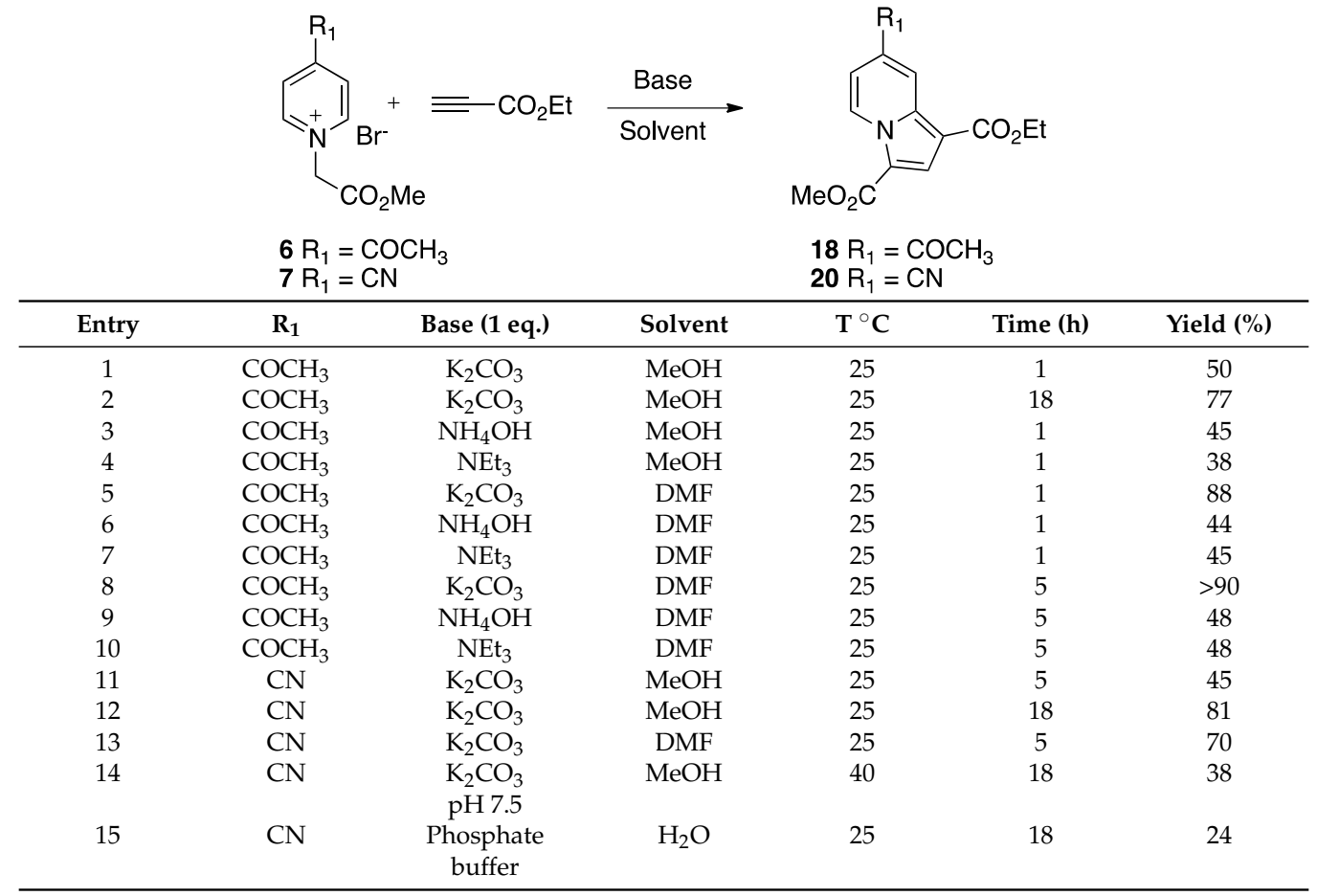


$\mathrm{K}_{2} \mathrm{CO}_{3}$ appeared as the most efficient base in both solvents (entries 1 and 5), and DMF emerged as the best choice to perform reactions with $6\left(\mathrm{R}_{1}=\mathrm{COCH}_{3}\right)$. The reaction proceeded quickly in this solvent with good yield obtained in $1 \mathrm{~h}$ (entry 5). Increasing the reaction time to $5 \mathrm{~h}$ (entry 8) did not significantly improve the yield. This solvent effect was also observed with the 4-cyano analog 7 , for which both solvents may be alternatively used. Still, the reaction remained faster in DMF than in methanol (compare entries 11 and 13). The reaction was attempted at a higher temperature in methanol (entries 12 and 14), but leading to the formation of side-products including those resulting from trans-esterification.

The reaction was also performed in $\mathrm{pH} 7.5$ phosphate buffer (entry 15). The pyridinium salt 7 was soluble in aqueous solution, but the hydrophobic nature of the ethyl propiolate was a severe limitation. Nevertheless, we were thrilled to isolate the resulting indolizine 20 in $24 \%$ yield. This result indicated that the pKa of the salt (8.16 for 7 ) was compatible with the partial formation of the ylide under these conditions, thus allowing the cycloaddition reaction. It should be noted that, to our knowledge, dipolar cycloaddition involving a pyridinium ylide in neutral aqueous solution has not been reported so far.

In an effort to increase the reactivity in water, the reaction was performed with compounds 11-13 that displayed lower $\mathrm{pKa}$ values and would mainly exist as ylides at $\mathrm{pH}$ 7.5. The reactions were performed in $\mathrm{pH} 7.5$ buffer solutions. For solubility reasons, the first attempts were made at $40^{\circ} \mathrm{C}$ in Tris buffer. As indicated in Table 4, the cyclization was highly dependent on the nature of the substituent at position 4 . There was no reaction with the unsubstituted pyridinium $\mathbf{1 1}$ (entry 1), and a low yield in indolizine 22 was obtained from the 4-acetyl pyridinium 12 (entry 2). The 4-cyanopyridinium 13 yielded the indolizine 23 in a reasonable $40 \%$ yield. As we had previously observed a negative effect of temperature on yields, the reaction was then performed at $25^{\circ} \mathrm{C}$ under vigorous stirring and, as a result, the yield jumped to 63\% (entry 4). Replacing Tris buffer with phosphate buffer (entry 5) had a negative effect on the yield that dropped to $42 \%$. For comparison, the reactivity of $\mathbf{1 3}$ in organic solvents was investigated (entries 6 and 7). A very strong solvent effect was observed. While no formation of 23 occurred in methanol, it was isolated in excellent yield in DMF. The difference in reactivity between $\mathbf{1 2}$ and $\mathbf{1 3}$ in Tris buffer may be due to the unfavorable formation of the hydrate form of 12. However, these first data confirmed the feasibility of this dipolar cycloaddition in aqueous solutions starting with 4-cyanopyridinium salts 7 and 13.

Table 4. Formation of indolizine from diethyl dicarboxylate substituted pyridinium 11-13 in $\mathrm{pH} 7.5$ buffer solutions.

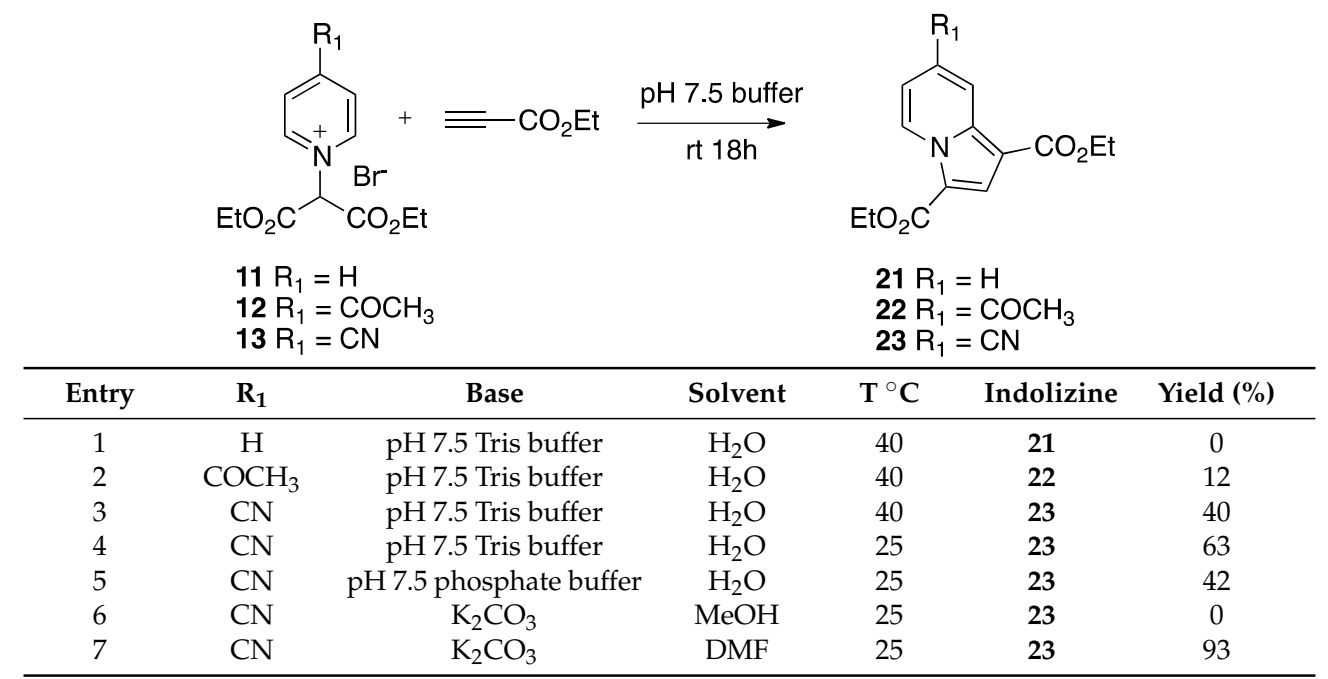

The mixtures of pyridinium salts (1 eq.) and ethyl propiolate (1.5 eq.) were stirred at the chosen temperatures for $18 \mathrm{~h}$. Results are given as yields of isolated indolizines. 


\subsubsection{Effect of the $R_{2}$ Group}

To extend the scope of the reaction, it was also important to compare the reactivity of pyridinium salts containing various methylene $R_{2}$ substituents. As shown in Table 5 , the yield in 7-cyanoindolizine was higher starting from the methyl ester $\mathbf{7}$ than from benzoyl derivatives $\mathbf{8}$ or $\mathbf{9}$. The presence of the nitro group on the phenyl ring, lowering the $\mathrm{pH}$ of ylide formation, slightly increased the yield (compare entries 2 and 3).

Table 5. Effect of the nature of $R_{2}$ group on the yield of 7-cyanoquinazolines.
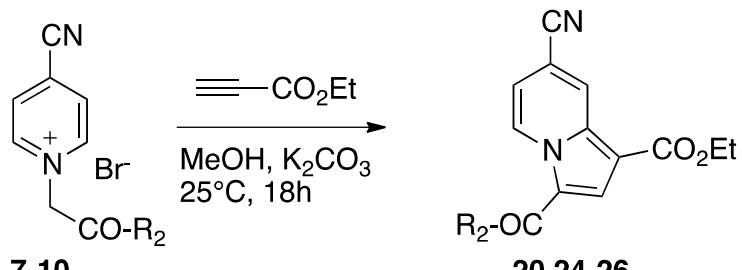

7-10

20,24-26

\begin{tabular}{ccccc}
\hline Entry & Pyridinium Salt & $\mathbf{R}_{\mathbf{2}}$ & Indolizine & Yield (\%) \\
\hline 1 & $\mathbf{7}$ & $\mathrm{OMe}$ & $\mathbf{2 0}$ & 81 \\
2 & $\mathbf{8}$ & $\mathbf{P h}$ & $\mathbf{2 4}$ & 50 \\
3 & $\mathbf{9}$ & $\mathrm{C}_{\mathbf{6}} \mathrm{H}_{4} \mathrm{NO}_{2}$ & $\mathbf{2 5}$ & 67 \\
4 & $\mathbf{1 0}$ & $\mathrm{NHC}_{3} \mathrm{H}_{7}$ & $\mathbf{2 6}$ & 62 \\
\hline
\end{tabular}

The pyridinium salts and 1.5 equivalents of ethyl propiolate were stirred in methanol in the presence of $\mathrm{K}_{2} \mathrm{CO}_{3}$ (1 eq.) for $18 \mathrm{~h}$ at room temperature.

An interesting result was obtained with the amide containing pyridinium salt 10. The yield of indolizine 26 was moderate (62\%), but this result was important as it gives an interesting alternative to the ester as a potential reactant, and this approach has not been reported so far in the literature.

\subsubsection{Influence of the Dipolarophile}

The last parameter to evaluate was the nature of the dipolarophile. As shown in Table 6, the reaction worked also well with propiolic amide such as 27 , giving the corresponding indolizine 28 in reasonable (not optimized) yield. With substituted propiolate, such as $\mathbf{2 9}$, a complex mixture of indolizines was obtained as shown by the presence of several fluorescent spots on TLC. No reaction was observed with less activated alkynes, as exemplified by 30 or $\mathbf{3 1}$.

Table 6. Reaction of 4-cyanopyridinium salt 7 with various dipolarophiles.

Entry Dipolarophile


Table 6. Cont.

\begin{tabular}{lll}
\hline Entry & Dipolarophile & Indolizine (Yield) \\
\hline 5 & & \\
\hline
\end{tabular}

Stoichiometric amounts of 4-cyanopyridinium 7, the chosen dipolarophile and $\mathrm{K}_{2} \mathrm{CO}_{3}$ in methanol were stirred at room temperature for $18 \mathrm{~h}$. Yields are given after purification of the indolizines by column chromatography (elution EtOAc/cyclohexane).

Again, it is important to emphasize the mild conditions used in this study. Simple pyridinium ylides were shown to react at high temperatures with isolated alkynes [39]. However the lack of reactivity with isolated alkynes at room temperature may be useful as it allows the introduction of an isolated triple bond in the reactants for further orthogonal reactions.

\section{Discussion}

To summarize, the highest yields of indolizines were obtained when both partners of the reaction, the pyridinium salt (or the corresponding ylide) and the triple bond, were substituted with a strong electron-withdrawing group (acetyl, cyano, ester, or amide). The mechanism of the cycloaddition has been discussed in the literature. The reactions of pyridinium ylides with propiolates are generally described as concerted OM-controlled reactions [33,40,43,44]. Matsumoto [41] also reported the inverse electron-demand cycloaddition of cyclooctyne with pyridinium bis(methoxycarbonyl)methylides similar to 11. However, Shang and colleagues [39] found that, in the reaction with simple alkynes in $\mathrm{DMF}-\mathrm{K}_{2} \mathrm{CO}_{3}$ at high temperature $\left(120^{\circ} \mathrm{C}\right)$, the presence of electron-donating or -withdrawing substituents on the ylides significantly lowered the yields in indolizines.

The importance of electron-withdrawing groups on both reactants is in favor of the two-step mechanism depicted in Scheme 2, involving the Michael addition of the ylide to the triple bond, with formation of zwitterionic allenoate intermediate followed by the intramolecular 5-endo trig cyclization. However, one also has to keep in mind that the very first step is not the cycloaddition itself, but the formation and stabilization of the reactive ylides that are also favored by electron-withdrawing groups.<smiles>[R]C(=O)c1cc(OCC)c2cc([R1])ccn12</smiles>

Scheme 2. Alternative two-step mechanism.

In conclusion, the reaction of pyridinium ylides with propiolic acid derivatives was explored in the perspective of its use as coupling reaction. The reaction was investigated by varying a set of parameters, i.e., the nature of the substituents, the reaction conditions, and the nature of the dipolarophile. First of all, the regioselectivity of the reaction is a positive aspect for this application. The presence of an electron-withdrawing group at position 4 of the pyridinium salt (exemplified with 4-cyano or 4-acetyl derivatives) allowed the reaction with propiolic ester or amide to proceed in mild conditions in a 
variety of solvents. The reaction progression was easily monitored by TLC, due to the fluorescence of the newly-formed indolizine. This point is of major interest is that, so far, most pro-fluorescent click reactions involve the use of added fluorogenic or fluorescent heterocycles [50,51].

A second key result was the reactivity in neutral aqueous solutions at room temperature. Indeed, the presence of the electron-withdrawing group at position 4 played an essential role in the formation and stabilization of the reactive ylides in these conditions. The main limitation appeared to be the water solubility of the propiolic ester.

This study allowed us to select the best partners and conditions for a highly modular pro-fluorescent click-type coupling reaction. The reactants include a pyridine containing an electron-withdrawing group (CN, $\mathrm{COR}, \mathrm{CO}_{2} \mathrm{R}, \mathrm{CONHR}$, etc.) at position 4, a 2-bromo-acetyl ester or amide, and a propiolic ester or amide. Interestingly, this methodology appears complementary to the tetrazine-alkene reaction $[52,53]$ involving an electron-rich dipolarophile, but yielding non-fluorescent compounds.

\section{Experimental Section}

\subsection{Material and Methods}

Melting points were determined using a Reichert Thermovar apparatus (Depew, NW, USA) and are uncorrected. NMR spectra were recorded on the Bruker Avance 400 spectrometer (Bruker Corporation, Billerica, MA, USA) of the "Fédération de Recherche" ICMG (FR2607) platform, using the solvent as the internal reference; the chemical shifts are reported in parts per million (ppm) units. High-resolution mass spectra (HRMS) were performed on a Bruker maXis mass spectrometer Q-TOF (Bruker Corporation) by the "Fédération de Recherche" ICOA/CBM (FR2708) platform. Reversed-phase HPLC was performed with a $\mu$-bondapak-C18 analytical column (Waters Corporation, Milford, MA, USA). A Waters chromatographic system was used, with two M-510 pumps and a photodiode array detector Waters 996 using Millenium 32 software. A linear gradient from 0 to $100 \%$ methanol in $\mathrm{H}_{2} \mathrm{O}$ pH 2.5 (phosphoric acid), $2 \mathrm{~mL} / \mathrm{min}$ flow rate, was used.

The reagents were purchased from Sigma Aldrich and were used without further purification. $N$-Benzylprop-2-ynamide 27 was prepared by biocatalyzed reaction between benzylamine and ethyl propiolate as reported recently by us [54]. Ethyl 3-ethynylbenzoate $\mathbf{3 0}$ was prepared by esterification of 3-ethynylbenzoic acid following reported procedure [55].

Calculator Plugins were used for structure property prediction and calculation, Marvin 6.0.2 , 2013, ChemAxon (http:/ / www.chemaxon.com).

Copies of the NMR spectra and HPLC chromatograms of the new compounds may be found in the Supplementary Materials.

\subsection{General Methods for the Synthesis of N-Heterocyclic Salts}

Method A: The pyridine derivative (1 eq.) and the alkylating reagent (1.5 eq) were dissolved in dry acetone ( $2 \mathrm{~mL}$ for $1 \mathrm{mmol}$ of pyridine derivative). The reaction mixture was stirred in an ultra-sound bath for $5 \mathrm{~h}$ to $10 \mathrm{~h}$, depending on the nature of substituent present on the pyridine. The temperature of the bath was kept under $50{ }^{\circ} \mathrm{C}$ by adding ice is necessary. Then, a non-polar solvent (3 to $5 \mathrm{~mL}$ of $\mathrm{Et}_{2} \mathrm{O}$ or DCM) was added, and the quaternary salt that deposited was filtered off, and washed with DCM.

Method B: The reactions between the pyridine derivatives and diethyl iodomalonate were performed in acetone in the presence of a large excess of reactant, the mixture being stirred at room temperature for two days. Then, $\mathrm{Et}_{2} \mathrm{O}$ was added to the flask and the quaternary hygroscopic salt was filtered off and washed with DCM and/or $\mathrm{Et}_{2} \mathrm{O}$.

1-(2-Methoxy-2-oxoethyl)pyridinium bromide (1) was prepared according to the general method A from pyridine (1 mmol) and methyl 2-bromoacetate. The resulting pyridinium 1 was obtained in $71 \%$ yield 
(165 mg) as a white powder. mp $167-168{ }^{\circ} \mathrm{C}$ [lit. [56] 174-175 ${ }^{\circ} \mathrm{C}$ ]; ${ }^{1} \mathrm{H}-\mathrm{NMR}\left(400 \mathrm{MHz}, \mathrm{CD}_{3} \mathrm{OD}\right) \delta 9.01$ $(\mathrm{dd}, 2 \mathrm{H}, J=6.8,1.2 \mathrm{~Hz}), 8.74(\mathrm{~m}, 1 \mathrm{H}), 8.23(\mathrm{t}, 2 \mathrm{H}, J=7.6,6.8 \mathrm{~Hz}), 5.66(\mathrm{~s}, 2 \mathrm{H}), 3.90(\mathrm{~s}, 3 \mathrm{H})$.

4-Amino-1-(2-methoxy-2-oxoethyl)pyridinium bromide (2) was prepared according to the general method A from 4-aminopyridine $(1 \mathrm{mmol})$ and methyl 2-bromoacetate. The resulting pyridinium salt 2 was obtained in $83 \%$ yield $(205 \mathrm{mg})$ as a white powder. mp $268-269{ }^{\circ} \mathrm{C}$ [lit. [57] 175-176 ${ }^{\circ} \mathrm{C}$ ]; ${ }^{1} \mathrm{H}-\mathrm{NMR}$ $\left(400 \mathrm{MHz}, \mathrm{CD}_{3} \mathrm{OD}\right) \delta 8.09(\mathrm{dd}, J=6 \mathrm{~Hz}, 2 \mathrm{H}), 6.92(\mathrm{dd}, J=6 \mathrm{~Hz}, 2 \mathrm{H}), 5.12(\mathrm{~s}, 2 \mathrm{H}), 3.86(\mathrm{~s}, 3 \mathrm{H})$.

4-Acetamido-1-(2-methoxy-2-oxoethyl)pyridinium bromide (3) was prepared according to the general method A from 4-acetamidopyridine $(1 \mathrm{mmol})$ and methyl 2-bromoacetate The resulting pyridinium salt 3 was obtained in $81 \%$ yield $(234 \mathrm{mg})$ as a white powder. mp $104-106{ }^{\circ} \mathrm{C} ;{ }^{1} \mathrm{H}-\mathrm{NMR}(400 \mathrm{MHz}$, DMSO- $\left._{6}\right) \delta 11.61(\mathrm{~s}, 1 \mathrm{H}), 8.74(\mathrm{~d}, 2 \mathrm{H}, J=7.6 \mathrm{~Hz}), 8.14(\mathrm{~d}, 2 \mathrm{H}, J=7.2 \mathrm{~Hz}), 5.51(\mathrm{~s}, 2 \mathrm{H}), 3.78(\mathrm{~s}, 3 \mathrm{H}), 2.26$ $(\mathrm{s}, 3 \mathrm{H}) ;{ }^{13} \mathrm{C}-\mathrm{NMR}\left(100 \mathrm{MHz}, \mathrm{DMSO}-d_{6}\right) \delta 171.1,167.3,152.5,146.6,114.3,58.6,53.0,24.7$; HRMS (ESI) $\mathrm{m} / \mathrm{z}$ calcd for $\mathrm{C}_{10} \mathrm{H}_{13} \mathrm{~N}_{2} \mathrm{O}_{3}$ 209.0926, obsd 209.0919.

4-Trifluoromethyl-1-(2-methoxy-2-oxoethyl)pyridinium bromide (4) was prepared according to the general method A from commercial 4-trifluoromethylpyridine $(2 \mathrm{mmol})$ and methyl 2-bromoacetate. The resulting quaternary salt 4 was obtained in $54 \%$ yield $(162 \mathrm{mg})$ as a yellow powder. mp $127-130{ }^{\circ} \mathrm{C}$; ${ }^{1} \mathrm{H}-\mathrm{NMR}\left(400 \mathrm{MHz}, \mathrm{CD}_{3} \mathrm{OD}\right) \delta 9.39(\mathrm{~d}, 2 \mathrm{H}, J=6.8 \mathrm{~Hz}), 8.66(\mathrm{~d}, 2 \mathrm{H}, J=6.8 \mathrm{~Hz}), 5.83(\mathrm{~s}, 2 \mathrm{H}), 3.94(\mathrm{~s}, 3 \mathrm{H})$; ${ }^{13} \mathrm{C}-\mathrm{NMR}\left(100 \mathrm{MHz}, \mathrm{CD}_{3} \mathrm{OD}\right) \delta$ 165.9, 148.6 (2C), 145.9, 145.5, 124.6 (2C), 122.5, 119.8, 61.0, 52.8; HRMS (ESI) $m / z$ calcd for $\mathrm{C}_{9} \mathrm{H}_{9} \mathrm{~F}_{3} \mathrm{NO}_{2} 220.0577$, obsd 220.0580 .

4-(N-Propylcarbamoyl)-1-(2-methoxy-2-oxoethyl)pyridinium bromide (5) was pepared according to the general method A from 4- $\mathrm{N}$-propylcarbamoylpyridine $(0.9 \mathrm{mmol})$ and methyl 2-bromoacetate. The resulting quaternary salt 5 was obtained in $80 \%$ yield $(231 \mathrm{mg})$ as an orange powder. $\mathrm{mp}$ 136-138 ${ }^{\circ} \mathrm{C} ;{ }^{1} \mathrm{H}-\mathrm{NMR}\left(400 \mathrm{MHz}, \mathrm{CD}_{3} \mathrm{OD}\right) \delta 9.19(\mathrm{dd}, 2 \mathrm{H}, J=6.4 \mathrm{~Hz}) ; 8.52(\mathrm{dd}, 2 \mathrm{H}, J=6.4 \mathrm{~Hz})$, $5.75(\mathrm{~s}, 2 \mathrm{H}), 3.92(\mathrm{~s}, 3 \mathrm{H}), 3.46(\mathrm{t}, 2 \mathrm{H}, J=7.4 \mathrm{~Hz}), 1.71-1.76(\mathrm{~m}, 2 \mathrm{H}), 1.05(\mathrm{t}, 3 \mathrm{H}, J=7.4 \mathrm{~Hz}) ;{ }^{13} \mathrm{C}-\mathrm{NMR}$ (100 MHz, CD $\left.{ }_{3} \mathrm{OD}\right) \delta 167.6,164.0,151.8,148.6$ (2C), 1267.0 (2C), 61.8, 54.1, 43.3, 23.4, 11.7; HRMS (ESI) $m / z:[\mathrm{M}+\mathrm{H}]^{+}$calcd for $\mathrm{C}_{12} \mathrm{H}_{17} \mathrm{~N}_{2} \mathrm{O}_{3} 237.1234$, obsd 237.1232.

4-Acetyl-1-(2-methoxy-2-oxoethyl)pyridinium bromide (6) was prepared according to the general method A from 4-acetylpyridine $(4.1 \mathrm{mmol})$ and methyl 2-bromoacetate. The resulting quaternary salt 6 was obtained in $64 \%$ yield $(716 \mathrm{mg})$ as a red powder. mp $149-150{ }^{\circ} \mathrm{C} ;{ }^{1} \mathrm{H}-\mathrm{NMR}\left(400 \mathrm{MHz}, \mathrm{CD}_{3} \mathrm{OD}\right) \delta 9.35$ $(\mathrm{dd}, 2 \mathrm{H}, J=6.8 \mathrm{~Hz}) ; 8.63(\mathrm{dd}, 2 \mathrm{H}, J=6.8 \mathrm{~Hz}) ; 5.88\left(\mathrm{~s}, 2 \mathrm{H}, \mathrm{CH}_{2}\right) ; 3.80\left(\mathrm{~s}, 3 \mathrm{H}, \mathrm{OCH}_{3}\right), 2.78\left(\mathrm{~s}, 3 \mathrm{H}, \mathrm{CH}_{3}\right) ;$ ${ }^{13} \mathrm{C}-\mathrm{NMR}\left(100 \mathrm{MHz}, \mathrm{DMSO}-d_{6}\right) \delta 195.5,166.6,149.2,147.8$ (2C), 125.7 (2C), 60.4, 53.3, 27.5; HRMS (ESI) $\mathrm{m} / \mathrm{z}$ calcd for $\mathrm{C}_{10} \mathrm{H}_{12} \mathrm{NO}_{3}$ 194.0812, obsd 194.0810.

4-Cyano-1-(2-methoxy-2-oxoethyl)pyridinium bromide (7) was prepared according to the general method A from 4-cyanopyridine $(1 \mathrm{mmol})$ and methyl 2-bromoacetate. The resulting pyridinium salt 7 was obtained in $60 \%$ yield $(154 \mathrm{mg})$ as a white powder. mp $208-209{ }^{\circ} \mathrm{C}$ [lit. [58] 181-183 ${ }^{\circ} \mathrm{C}$ ]; ${ }^{1} \mathrm{H}-\mathrm{NMR}$ $\left(400 \mathrm{MHz}, \mathrm{CD}_{3} \mathrm{OD}\right) \delta 9.29(\mathrm{dd}, 2 \mathrm{H}, J=5.4 \mathrm{~Hz}), 8.64(\mathrm{dd}, 2 \mathrm{H}, J=5.4 \mathrm{~Hz}), 5.75(\mathrm{~s}, 2 \mathrm{H}), 3.92(\mathrm{~s}, 3 \mathrm{H})$.

4-Cyano-1-(2-oxo-2-phenylethyl)pyridinium iodide (8) was prepared according to the general method B from commercial 4-cyanopyridine $(2 \mathrm{mmol}$ ) and 2-iodo-acetophenone. The resulting pyridinium salt 8 was obtained in $70 \%$ yield (493 mg) as a red powder. mp 132-134 ${ }^{\circ} \mathrm{C}$ [lit. [47] $114-118{ }^{\circ} \mathrm{C}$ ]; ${ }^{1} \mathrm{H}-\mathrm{NMR}$ $\left(400 \mathrm{MHz}, \mathrm{DMSO}-d_{6}\right) \delta 9.30(\mathrm{~d}, 2 \mathrm{H}, J=6.9 \mathrm{~Hz}), 8.84(\mathrm{~d}, 2 \mathrm{H}, J=6.9 \mathrm{~Hz}), 8.09(\mathrm{dd}, 2 \mathrm{H}, J=8.5,7.1 \mathrm{~Hz})$, 7.80-7.85 (m, 1H), 7.67-7.72 (m, 2H), $6.61(\mathrm{~s}, 2 \mathrm{H})$.

4-Cyano-1-(2-oxo-2-(para-nitrophenyl)ethyl)pyridinium iodide (9) was prepared according to the general method A from commercial 4-cyanopyridine $(1 \mathrm{mmol})$ and 2-iodo-4-nitroacetophenone. The resulting quaternary salt 9 was obtained in $60 \%$ yield $(239 \mathrm{mg})$ as a yellow powder. $\mathrm{mp} 182-184{ }^{\circ} \mathrm{C}$ [lit. [47] 187-189 $\left.{ }^{\circ} \mathrm{C}\right] ;{ }^{13} \mathrm{C}-\mathrm{NMR}\left(100 \mathrm{MHz}, \mathrm{DMSO}-d_{6}\right) \delta 189.2,150.7,147.6(2 \mathrm{C}), 138.0,130.8(2 \mathrm{C}), 129.8(2 \mathrm{C})$, 128.1, 124.2 (2C), 114.8, 67.3. 
4-Cyano-1-[(N-propylcarbamoyl)methyl]pyridinium bromide (10) was prepared according to the general method A from 4-cyanopyridine $(1 \mathrm{mmol})$ and 2-bromo- $N$-propylacetamide. The resulting pyridinium-salt 10 was obtained in $60 \%$ yield $(160 \mathrm{mg})$ as a yellow powder. $\mathrm{mp} 185-186{ }^{\circ} \mathrm{C} ;{ }^{1} \mathrm{H}-\mathrm{NMR}$ $\left(400 \mathrm{MHz}, \mathrm{CD}_{3} \mathrm{OD}\right) \delta 9.24(\mathrm{~d}, 2 \mathrm{H}, J=6.8 \mathrm{~Hz}), 8.59(\mathrm{~d}, 2 \mathrm{H}, J=6.8 \mathrm{~Hz}), 5.60(\mathrm{~s}, 2 \mathrm{H}), 3.26(\mathrm{t}, 2 \mathrm{H}, J=7.2 \mathrm{~Hz})$, 1.58-1.64 (m, 2H), 0.99 (t, 3H, J = 7.2 Hz); ${ }^{13} \mathrm{C}-\mathrm{NMR}\left(100 \mathrm{MHz}, \mathrm{CD}_{3} \mathrm{OD}\right) \delta$ 165.0, 149.1 (2C), 131.7 (2C), 130.4, 115.3, 63.9, 42.9, 23.5, 11.8; HRMS (ESI) m/z: $[\mathrm{M}+\mathrm{H}]^{+}$calcd for $\mathrm{C}_{11} \mathrm{H}_{14} \mathrm{~N}_{3} \mathrm{O} 204.1131$, obsd 204.1132 .

1-(1,3-Diethoxy-1,3-dioxopropan-2-yl)pyridinium iodide (11) was prepared according to the general method $\mathrm{B}$ from pyridine $(5.5 \mathrm{mmol})$ and ethyl 2-iodomalonate. The resulting quaternary salt 11 was obtained in $89 \%$ yield $(1.80 \mathrm{~g})$ as a white powder. mp 151-152 ${ }^{\circ} \mathrm{C}$ [lit. [59] 154-155 ${ }^{\circ} \mathrm{C}$ ]; ${ }^{1} \mathrm{H}-\mathrm{NMR}(400 \mathrm{MHz}$, $\left.\mathrm{CD}_{3} \mathrm{OD}\right) \delta 9.20(\mathrm{t}, 2 \mathrm{H}, J=7.2 \mathrm{~Hz}), 8.81-8.85(\mathrm{~m}, 1 \mathrm{H}), 8.28(\mathrm{dd}, 2 \mathrm{H}, J=7.2 \mathrm{~Hz}, 8 \mathrm{~Hz}), 4.37-4.52(\mathrm{~m}, 4 \mathrm{H})$, $1.40(\mathrm{t}, 6 \mathrm{H}, J=7.2 \mathrm{~Hz})$.

4-Acetyl-1-(1,3-diethoxy-1,3-dioxopropan-2-yl)pyridinium iodide (12) was prepared according to the general method B from 4-acetylpyridine (4 mmol) and ethyl 2-iodomalonate. The resulting pyridinium-salt 12 was obtained in $99 \%$ yield (1.66 g) as a yellow powder. mp 130-131 ${ }^{\circ} \mathrm{C}$ [lit. [37]: 196-198 ${ }^{\circ} \mathrm{C}$ ]; ${ }^{1} \mathrm{H}-\mathrm{NMR}$ $\left(400 \mathrm{MHz}, \mathrm{CD}_{3} \mathrm{OD}\right) \delta 9.36(\mathrm{~d}, 2 \mathrm{H}, J=7.0 \mathrm{~Hz}), 8.61(\mathrm{~d}, 2 \mathrm{H}, J=7.0 \mathrm{~Hz}), 4.39-4.51(\mathrm{~m}, 4 \mathrm{H}), 2.84(\mathrm{~s}, 3 \mathrm{H})$, $1.41(\mathrm{t}, 6 \mathrm{H}, J=7.1 \mathrm{~Hz})$.

4-Cyano-1-(1,3-diethoxy-1,3-dioxopropan-2-yl)pyridinium iodide (13) [37] was prepared according to the general method B from 4-cyanopyridine $(4.8 \mathrm{mmol})$ and ethyl 2-iodomalonate. The resulting pyridinium-salt 13 was obtained in $40 \%$ yield $(750 \mathrm{mg})$ as a white powder. $\mathrm{mp} 120-122{ }^{\circ} \mathrm{C}$ [lit. [37] $240{ }^{\circ} \mathrm{C}$ decomposed]; ${ }^{13} \mathrm{C}-\mathrm{NMR}\left(100 \mathrm{MHz}, \mathrm{CD}_{3} \mathrm{OD}\right) \delta 163.3$ (2C), 151.6, 149.7 (2C), 132.0, 131.4 (2C), $115.2,65.8(2 \mathrm{C}), 14.2(2 \mathrm{C})$.

\subsection{General Methods for the Ylide-Alkyne Cycloaddition}

Method C: The cycloaddition was performed with 1 eq. of the quaternary salt, 1.1 eq. of the alkyne derivative, and 1 eq. of $\mathrm{K}_{2} \mathrm{CO}_{3}$ in methanol or DMF. The $\mathrm{pH}$ of the solution was close to 9. The reaction mixture was stirred at room temperature under air atmosphere for $18 \mathrm{~h}$. Then, water was added and the corresponding indolizine was precipitated, filtered off and washed with water.

Method D: The cycloaddition was performed in Tris-buffer pH 7.5 (Tris-buffered saline tablets from sigma, one tablet dissolved in $15 \mathrm{~mL}$ of deionized water produces $50 \mathrm{mM}$ Tris- $\mathrm{HCl}, 150 \mathrm{mM}$ sodium chloride) with 1 eq. of the quaternary salt and $1.1 \mathrm{eq}$ of the alkyne derivative. The reaction mixture was stirred at $40{ }^{\circ} \mathrm{C}$ under air atmosphere for $18 \mathrm{~h}$. Then, the reaction mixture cooled in an ice bath, and the precipitate that formed was filtered off and washed with water.

1-Ethyl 3-methyl indolizine-1,3-dicarboxylate (14). The reaction was performed with 1 (100 mg) and ethyl propiolate in methanol, following method C. The indolizine 14 was obtained in $59 \%$ yield (63 mg) as a white powder. mp 97-99 ${ }^{\circ} \mathrm{C}$ [lit. [60] 92-93 ${ }^{\circ} \mathrm{C}$ ]; ${ }^{1} \mathrm{H}-\mathrm{NMR}\left(400 \mathrm{MHz}, \mathrm{CDCl}_{3}\right) \delta 9.56(\mathrm{dd}, 1 \mathrm{H}, \mathrm{J}=7.0$, $1.2 \mathrm{~Hz}), 8.34(\mathrm{~m}, 1 \mathrm{H}), 8.04(\mathrm{~s}, 1 \mathrm{H}), 7.37(\mathrm{~m}, 1 \mathrm{H}), 7.04(\mathrm{td}, 1 \mathrm{H}, J=6.8,1.2 \mathrm{~Hz}), 4.43(\mathrm{q}, 2 \mathrm{H}, J=7.2 \mathrm{~Hz}), 3.97$ $(\mathrm{s}, 3 \mathrm{H}), 1.47(\mathrm{t}, 3 \mathrm{H}, J=7.2 \mathrm{~Hz})$.

1-Ethyl 3-methyl 7-(propylcarbamoyl)indolizine-1,3-dicarboxylate (17). The reaction was performed with $5(40 \mathrm{mg})$ and ethyl propiolate in methanol, following method $\mathrm{C}$. The indolizine $\mathbf{1 7}$ was obtained in $66 \%$ yield $(27 \mathrm{mg})$ as a white powder. mp $159-161^{\circ} \mathrm{C} ;{ }^{1} \mathrm{H}-\mathrm{NMR}\left(400 \mathrm{MHz}, \mathrm{CDCl}_{3}\right) \delta 9.52(\mathrm{~m}, 1 \mathrm{H})$, $8.64(\mathrm{dd}, 1 \mathrm{H}, J=1.2 \mathrm{~Hz}, 2.0 \mathrm{~Hz}), 8.00$ (s, 1H), $7.47(\mathrm{dd}, 1 \mathrm{H}, J=2.0 \mathrm{~Hz}, 5.2 \mathrm{~Hz}), 6.38$ (s br, $1 \mathrm{H}), 4.39$ $(\mathrm{q}, 2 \mathrm{H}, J=7.2 \mathrm{~Hz}), 3.94(\mathrm{~s}, 3 \mathrm{H}), 3.46(\mathrm{~m}, 2 \mathrm{H}), 1.68(\mathrm{q}, 2 \mathrm{H}, J=7.2 \mathrm{~Hz}), 1.43(\mathrm{t}, 3 \mathrm{H}, J=7.2 \mathrm{~Hz}), 1.01(\mathrm{t}, 3 \mathrm{H}$, $J=7.2 \mathrm{~Hz}) ;{ }^{13} \mathrm{C}-\mathrm{NMR}\left(100 \mathrm{MHz}, \mathrm{CDCl}_{3}\right) \delta 165.3,164.1,161.3,137.7,131.4,127.9,124.7,117.1,115.6$, 113.1, 107.3, 60.3, 51.7, 42.0, 22.9, 14.5, 11.5; HRMS (ESI) m/z: $[\mathrm{M}+\mathrm{H}]^{+}$calcd for $\mathrm{C}_{17} \mathrm{H}_{21} \mathrm{~N}_{2} \mathrm{O}_{5} 333.1443$, obsd 333.1445 . 
1-Ethyl 3-methyl 7-acetylindolizine-1,3-dicarboxylate (18). The reaction was performed with 6 (100 mg) and ethyl propiolate in methanol, following method $\mathrm{C}$. The indolizine 18 was obtained in $77 \%$ yield $(40 \mathrm{mg})$ as a red powder. mp $151-152{ }^{\circ} \mathrm{C} ;{ }^{1} \mathrm{H}-\mathrm{NMR}\left(400 \mathrm{MHz}, \mathrm{CDCl}_{3}\right) \delta 9.55(\mathrm{~m}, 1 \mathrm{H}), 8.98(\mathrm{~m}, 1 \mathrm{H}), 8.07$ (s, 1H), $7.57(\mathrm{dd}, 1 \mathrm{H}, J=7.4 \mathrm{~Hz}, 1.9 \mathrm{~Hz}), 5.34(\mathrm{~s}, 2 \mathrm{H}), 4.46(\mathrm{q}, 2 \mathrm{H}, J=7.2 \mathrm{~Hz}), 4.00(\mathrm{~s}, 3 \mathrm{H}), 2.75(\mathrm{~s}, 3 \mathrm{H})$, $1.49(\mathrm{t}, 3 \mathrm{H}, \mathrm{J}=7.2 \mathrm{~Hz}) ;{ }^{13} \mathrm{C}-\mathrm{NMR}\left(100 \mathrm{MHz}, \mathrm{CDCl}_{3}\right) \delta 196.0,163.8,161.3,137.5,132.8,127.6,124.8,121.4$, 116.4, 111.8, 109.0, 60.4, 51.8, 26.1, 14.5; HRMS (ESI) $m / z:[\mathrm{M}+\mathrm{H}]^{+}$calcd for $\mathrm{C}_{15} \mathrm{H}_{16} \mathrm{NO}_{5} 290.1023$, obsd. 290.1022, $[\mathrm{M}+\mathrm{Na}]^{+}$calcd for $\mathrm{C}_{15} \mathrm{H}_{15} \mathrm{NNaO}_{5}$ 312.0842, obsd. 312.0840.

1-Ethyl 3-methyl 7-(trifluoromethyl)indolizine-1,3-dicarboxylate (19a) and 1-methyl 3-methyl 7-(trifluoromethyl) indolizine-1,3-dicarboxylate (19b). The reaction was performed with 4 (50 $\mathrm{mg})$ and ethyl propiolate in methanol, following method C. The mixture of indolizines 19a and 19b (30/70 ratio) was obtained in $55 \%$ yield $(27 \mathrm{mg})$ as a yellow powder. ${ }^{1} \mathrm{H}-\mathrm{NMR}\left(400 \mathrm{MHz}, \mathrm{CDCl}_{3}\right) \delta 9.60(\mathrm{~d}, 1 \mathrm{H}, \mathrm{J}=7.2 \mathrm{~Hz}), 8.64(\mathrm{~s}$, $1 \mathrm{H}), 8.04(\mathrm{~s}, 1 \mathrm{H}), 7.12(\mathrm{dd}, 1 \mathrm{H}, J=7.2,2.0 \mathrm{~Hz}), 4.40\left(\mathrm{q}, 2 \mathrm{H}, J=7.2 \mathrm{~Hz}, \mathrm{CH}_{2}\right.$ of 19a), 3.95 and $3.94(2 \mathrm{~s}$, $2 \times 3 \mathrm{H}, \mathrm{OMe}$ of $19 \mathrm{a}$ and $19 \mathrm{~b}), 1.42\left(\mathrm{t}, 3 \mathrm{H}, J=7.2 \mathrm{~Hz}, \mathrm{CH}_{3}\right.$ of $\left.19 \mathrm{a}\right) ;{ }^{13} \mathrm{C}-\mathrm{NMR}\left(100 \mathrm{MHz}, \mathrm{CDCl}_{3}\right) \delta 164.0$, 163.5, 161.3, 136.8, 128.4,127.16, 125.7 (q, 225 Hz, CF $), 124.9,124.6,121.9,117.5,117.4,116.1,110.1$, 107.9, 60.5, 51.8, 51.6, 14.5; HRMS (ESI) 19a : $\mathrm{m} / z$ calcd for $\mathrm{C}_{14} \mathrm{H}_{13} \mathrm{~F}_{3} \mathrm{NO}_{4}$ 316.0791, obsd 316.0796, 19b: $m / z$ calcd for $\mathrm{C}_{13} \mathrm{H}_{11} \mathrm{~F}_{3} \mathrm{NO}_{4} 302.0635$, obsd 302.0638 .

1-Ethyl 3-methyl 7-cyanoindolizine-1,3-dicarboxylate (20). The reaction was performed with 7 (50 mg) and ethyl propiolate in methanol, following method $\mathrm{C}$. The indolizine 20 was obtained in $81 \%$ yield $(37 \mathrm{mg})$ as a white powder. $\mathrm{mp} 114-115{ }^{\circ} \mathrm{C} ;{ }^{1} \mathrm{H}-\mathrm{NMR}\left(400 \mathrm{MHz}, \mathrm{CDCl}_{3}\right) \delta 9.58(\mathrm{dd}, 1 \mathrm{H}, J=7.2,0.8 \mathrm{~Hz})$, 8.74-8.75 (m, 1H), $8.06(\mathrm{~s}, 1 \mathrm{H}), 7.07(\mathrm{dd}, 1 \mathrm{H}, J=7.2,2.0 \mathrm{~Hz}), 4.42(\mathrm{q}, 1 \mathrm{H}, J=7.0 \mathrm{~Hz}), 3.98(\mathrm{~s}, 3 \mathrm{H}), 1.44$ $(\mathrm{t}, 3 \mathrm{H}, J=7.2 \mathrm{~Hz}) ;{ }^{13} \mathrm{C}-\mathrm{NMR}\left(100 \mathrm{MHz}, \mathrm{CDCl}_{3}\right) \delta 163.2,161.1,136.0,128.2,125.9,125.1,117.5,114.1$, 109.0, 108.0, 60.7, 52.0, 14.5; HRMS (ESI) $m / z$ : $[\mathrm{M}+\mathrm{H}]^{+}$calcd for $\mathrm{C}_{14} \mathrm{H}_{13} \mathrm{~N}_{2} \mathrm{O}_{4}$ 273.0869, obsd 273.0870.

1,3-Diethyl 7-acetylindolizine-1,3-dicarboxylate (22) [61]. The reaction was performed with 12 (100 mg) and ethyl propiolate, following method D. The indolizine 22 was obtained in 12\% yield (9 mg) as a white powder. mp $125-127{ }^{\circ} \mathrm{C} .{ }^{1} \mathrm{H}-\mathrm{NMR}\left(400 \mathrm{MHz}, \mathrm{DMSO}-d_{6}\right) \delta 9.47(\mathrm{dd}, 1 \mathrm{H}, J=0.8,7.4 \mathrm{~Hz}), 8.81$ $(\mathrm{d}, 1 \mathrm{H}, J=0.8 \mathrm{~Hz}), 7.90(\mathrm{~s}, 1 \mathrm{H}), 7.62(\mathrm{dd}, 1 \mathrm{H}, J=1.9,7.4 \mathrm{~Hz}), 4.35-4.40(\mathrm{~m}, 4 \mathrm{H}), 2.69(\mathrm{~s}, 3 \mathrm{H}), 1.35-1.41$ $(\mathrm{m}, 6 \mathrm{H})$.

1,3-Diethyl 7-cyanoindolizine-1,3-dicarboxylate (23). The reaction was performed with 13 (15 mg) and ethyl propiolate, following method $\mathrm{D}$. The indolizine 23 was obtained in $40 \%$ yield $(4.9 \mathrm{mg})$ as a white powder. mp $103-104{ }^{\circ} \mathrm{C} ;{ }^{1} \mathrm{H}-\mathrm{NMR}\left(400 \mathrm{MHz}, \mathrm{CDCl}_{3}\right) \delta 9.64(\mathrm{dd}, 1 \mathrm{H}, J=0.8,7.2 \mathrm{~Hz}), 8.78(\mathrm{~s}, 1 \mathrm{H}), 8.11$ $(\mathrm{s}, 1 \mathrm{H}), 7.11(\mathrm{dd}, 1 \mathrm{H}, J=1.6,7.2 \mathrm{~Hz}), 4.45-4.50(\mathrm{~m}, 4 \mathrm{H}), 1.46-1.51(\mathrm{~m}, 6 \mathrm{H}) ;{ }^{13} \mathrm{C}-\mathrm{NMR}\left(100 \mathrm{MHz}, \mathrm{CDCl}_{3}\right)$ $\delta 163.2,161.1,136.1,128.2,125.8,125.0,117.5,116.9,114.1,109.0,108.0,61.4,60.7,52.0,14.5$ (identical to the commercial compound).

1-Ethyl 3-benzoyl-7-cyanoindolizine-1-carboxylate (24). The reaction was performed with 8 (50 mg) and ethyl propiolate in methanol, following method $\mathrm{C}$. The indolizine $\mathbf{2 4}$ was obtained in $50 \%$ yield (22.4 mg) as an orange powder. mp $136-137{ }^{\circ} \mathrm{C} ;{ }^{1} \mathrm{H}-\mathrm{NMR}\left(400 \mathrm{MHz}, \mathrm{CDCl}_{3}\right) \delta 9.99(\mathrm{~d}, 1 \mathrm{H}, \mathrm{J}=6.8 \mathrm{~Hz})$, $8.83(\mathrm{~s}, 1 \mathrm{H}), 7.95(\mathrm{~s}, 1 \mathrm{H}), 7.87(\mathrm{~d}, 2 \mathrm{H}, J=6.8 \mathrm{~Hz}), 7.67(\mathrm{~d}, 1 \mathrm{H}, J=6.4 \mathrm{~Hz}), 7.60(\mathrm{~d}, 2 \mathrm{H}, J=7.2 \mathrm{~Hz}), 7.20$ $(\mathrm{d}, 1 \mathrm{H}, J=6.8 \mathrm{~Hz}), 4.47(\mathrm{q}, 2 \mathrm{H}, J=7.2 \mathrm{~Hz}), 1.47(\mathrm{t}, 3 \mathrm{H}, J=7.2 \mathrm{~Hz}) ;{ }^{13} \mathrm{C}-\mathrm{NMR}\left(100 \mathrm{MHz}, \mathrm{CDCl}_{3}\right) \delta 186.1$, 163.2, 138.9, 136.9, 132.3, 129.3, 129.1, 129.0, 128.7, 128.4, 125.6, 124.2, 117.3, 114.8, 109.7, 109.4, 60.8, 14.53; HRMS (ESI) $m / z$ calcd for $\mathrm{C}_{19} \mathrm{H}_{15} \mathrm{~N}_{2} \mathrm{O}_{3} 319.1077$, obsd 319.1081.

1-Ethyl 3-(4-nitrobenzoyl)-7-cyanoindolizine-1-carboxylate (25). The reaction was performed with 9 (50 mg) and ethyl propiolate in methanol, following method $\mathrm{C}$. The indolizine 25 was obtained in $67 \%$ yield (29.6 mg) as a yellow powder. mp $143-144{ }^{\circ} \mathrm{C} ;{ }^{1} \mathrm{H}-\mathrm{NMR}\left(400 \mathrm{MHz}, \mathrm{CDCl}_{3}\right) \delta 9.92(\mathrm{~d}, 1 \mathrm{H}, \mathrm{J}=7.2 \mathrm{~Hz})$, $8.75(\mathrm{~s}, 1 \mathrm{H}), 8.34(\mathrm{~d}, 2 \mathrm{H}, J=8.5 \mathrm{~Hz}), 7.90(\mathrm{~d}, 2 \mathrm{H}, J=8.4 \mathrm{~Hz}), 7.76(\mathrm{~s}, 1 \mathrm{H}), 7.17(\mathrm{~m}, 1 \mathrm{H}), 4.35(\mathrm{q}, 2 \mathrm{H}, J=7.1$ $\mathrm{Hz}), 1.35$ (t, 3H, $J=7.1 \mathrm{~Hz}) ;{ }^{13} \mathrm{C}-\mathrm{NMR}\left(100 \mathrm{MHz}, \mathrm{CDCl}_{3}\right) \delta 183.9,163.0,150.0,144.3,137.7,130.1,129.9$, $129.6,129.3,125.9,124.1,123.9,123.6,117.2,115.7,110.9,110.2,61.2,14.7$; HRMS (ESI) $m / z:[\mathrm{M}+\mathrm{H}]^{+}$ calcd for $\mathrm{C}_{19} \mathrm{H}_{14} \mathrm{~N}_{3} \mathrm{O}_{5} 364.0927$, obsd 364.0928. 
1-Ethyl 7-cyano-3-(N-propylcarbamoyl)indolizine-1-carboxylate (26). The reaction was performed with 10 (20 mg) and ethyl propiolate in methanol, following method $\mathrm{C}$. The indolizine $\mathbf{2 6}$ was obtained in $62 \%$ yield $(15.6 \mathrm{mg})$ as a white powder. mp $170-171{ }^{\circ} \mathrm{C} ;{ }^{1} \mathrm{H}-\mathrm{NMR}\left(400 \mathrm{MHz}, \mathrm{CDCl}_{3}\right) \delta 9.83(\mathrm{dd}$, $1 \mathrm{H}, J=7.4,1.0 \mathrm{~Hz}), 8.75(\mathrm{dd}, 1 \mathrm{H}, J=1.8,1.0 \mathrm{~Hz}), 7.80(\mathrm{~s}, 1 \mathrm{H}), 7.08(\mathrm{dd}, 1 \mathrm{H}, J=7.4,1.8 \mathrm{~Hz}), 6.17$ (br s, $1 \mathrm{H}), 4.51(\mathrm{q}, 2 \mathrm{H}, J=7.2 \mathrm{~Hz}), 3.40-3.55(\mathrm{~m}, 2 \mathrm{H}), 1.72-1.79(\mathrm{~m}, 2 \mathrm{H}), 1.53(\mathrm{t}, 3 \mathrm{H}, J=7.2 \mathrm{~Hz}), 1.10(\mathrm{t}, 3 \mathrm{H}$, $J=7.2 \mathrm{~Hz}) ;{ }^{13} \mathrm{C}-\mathrm{NMR}\left(100 \mathrm{MHz}, \mathrm{CDCl}_{3}\right) \delta 163.4,160.7,135.1,128.7,125.8,119.9,119.2,117.7,113.4$, 108.2, 107.3, 60.7, 41.3, 23.0, 14.6, 11.5; HRMS (ESI) $m / z:[\mathrm{M}+\mathrm{H}]^{+}$calcd for $\mathrm{C}_{16} \mathrm{H}_{18} \mathrm{~N}_{3} \mathrm{O}_{3} 300.1342$, obsd 300.1348 .

Methyl 1-(N-benzylcarbamoyl)-7-cyanoindolizine-3-carboxylate (28). The reaction was performed with propiolamide 27 and pyridinium salt 7 (50 mg) in methanol, following method $C$. The indolizine 28 was obtained in $40 \%$ yield $(26 \mathrm{mg})$ as a white powder. mp $196-199{ }^{\circ} \mathrm{C} ;{ }^{1} \mathrm{H}-\mathrm{NMR}\left(400 \mathrm{MHz}, \mathrm{CDCl}_{3}\right) \delta$ $9.56(\mathrm{dd}, 1 \mathrm{H}, J=7.4,1.2 \mathrm{~Hz}), 9.07(\mathrm{dd}, 1 \mathrm{H}, J=1.8,1.2 \mathrm{~Hz}), 7.77(\mathrm{~s}, 1 \mathrm{H}), 7.42-7.44(\mathrm{~m}, 4 \mathrm{H}), 7.36-7.39$ $(\mathrm{m}, 1 \mathrm{H}), 7.10(\mathrm{dd}, 1 \mathrm{H}, J=7.4,1.8 \mathrm{~Hz}), 6.29$ (br s, $1 \mathrm{H}), 4.72(\mathrm{~d}, 2 \mathrm{H}, J=5.6 \mathrm{~Hz}), 3.99(\mathrm{~s}, 3 \mathrm{H}) ;{ }^{13} \mathrm{C}-\mathrm{NMR}$ $\left(100 \mathrm{MHz}, \mathrm{CDCl}_{3}\right) \delta 162.9,160.9,138.1,136.0,128.9$ (2C), 128.0 (2C), 127.8, 127.7, 126.8, 120.1, 117.5, 116.3, 114.2, 111.5, 107.5, 51.9, 43.7; HRMS (ESI) $m / z$ : $[\mathrm{M}+\mathrm{H}]^{+}$calcd for $\mathrm{C}_{19} \mathrm{H}_{16} \mathrm{~N}_{3} \mathrm{O}_{3} 334.1186$, obsd 334.1183, $[\mathrm{M}+\mathrm{Na}]^{+}$calcd for $\mathrm{C}_{19} \mathrm{H}_{15} \mathrm{~N}_{3} \mathrm{O}_{3}$ 356.1006, obsd. 356.1007.

\section{4. $p$ Ka Determination}

Potentiometric measurements were performed in a jacketed cell thermostated at $25.0^{\circ} \mathrm{C}$, kept under an inert atmosphere of purified argon, using an automatic titrator (Metrohm, DMS Titrino 716, Herisau, Switzerland) connected to a microcomputer. The free hydrogen concentrations were measured with a glass- $\mathrm{Ag} / \mathrm{AgCl}$ combined electrode (Metrohm) filled with $0.1 \mathrm{M} \mathrm{NaCl}$. The electrode was calibrated with three standard buffers at $\mathrm{pH} 4,7$, and $10 . \mathrm{NaCl}$ was employed as supporting electrolyte to maintain the ionic strength at $0.10 \mathrm{M}$.

Samples of $0.2 \mathrm{mmol}$ of pyridinium salts were dissolved in $20 \mathrm{~mL}$ of fresly prepared $0.1 \mathrm{M} \mathrm{NaClO}_{4}$. Aliquot of $10 \mathrm{~mL}$ were titrated with $0.02 \mathrm{M} \mathrm{NaOH}$. A minimum of three sets of data was used in each case. Equilibrium constants and species distribution diagrams were calculated by using the program HYPERQUAD 2003.

Supplementary Materials: Supplementary materials can be accessed at: http://www.mdpi.com/ 1420-3049/ 21/3/332/s1.

Acknowledgments: This work has been partly supported by the Labex ARCANE (ANR-11-LABX-0003-01) and by a grant of the Romanian National Authority for Scientific Research, CNCS-UEFISCDI project number PN-II-ID-PCE-2011-3-0226.

Author Contributions: M.D. and R.D. conceived the project; I.B. designed the experiments; S.B. and I.O.G. performed the experiments; M.D. and I.B. wrote the paper.

Conflicts of Interest: The authors declare no conflict of interest.

\section{Abbreviations}

The following abbreviations are used in this manuscript:

$\begin{array}{ll}\text { DMF } & N, N \text {-dimethylformamide } \\ \text { DMSO-D } & \text { deuterated dimethylsulfoxide } \\ \text { TLC } & \text { thin-layer chromatography } \\ \text { TRIS } & \text { Tris(hydroxymethyl)aminomethane }\end{array}$

\section{References}

1. Huang, W.; Zuo, T.; Luo, X.; Jin, H.; Liu, Z.; Yang, Z.; Yu, X.; Zhang, L.; Zhang, L. Indolizine derivatives as HIV-1 VIF-elongin C interaction inhibitors. Chem. Biol. Drug Des. 2013, 81, 730-741. [CrossRef] [PubMed] 
2. Singh, G.S.; Mmatli, E.E. Recent progress in synthesis and bioactivity studies of indolizines. Eur. J. Med. Chem. 2011, 46, 5237-5257. [CrossRef] [PubMed]

3. Vemula, V.R.; Vurukonda, S.; Bairi, C.K. Indolizine derivatives: Recent advances and potential pharmacological activities. Int. J. Pharm. Sci. Rev. Res. 2011, 11, 159-163.

4. Chen, S.; Xia, Z.; Nagai, M.; Lu, R.; Kostik, E.; Przewloka, T.; Song, M.; Chimmanamada, D.; James, D.; Zhang, S.; et al. Novel indolizine compounds as potent inhibitors of phosphodiesterase IV (PDE4): Structure-activity relationship. MedChemComm 2011, 2, 176. [CrossRef]

5. Shen, Y.M.; Lv, P.C.; Chen, W.; Liu, P.G.; Zhang, M.Z.; Zhu, H.L. Synthesis and antiproliferative activity of indolizine derivatives incorporating a cyclopropylcarbonyl group against Hep-G2 cancer cell line. Eur. J. Med. Chem. 2010, 45, 3184-3190. [CrossRef] [PubMed]

6. Cheng, Y.; Ma, B.; Wudl, F. Synthesis and optical properties of a series of pyrrolopyridazine derivatives: Deep blue organic luminophors for electroluminescent devices. J. Mater. Chem. 1999, 9, 2183-2188. [CrossRef]

7. Kim, E.; Koh, M.; Lim, B.J.; Park, S.B. Emission wavelength prediction of a full-color-tunable fluorescent core skeleton, 9-aryl-1,2-dihydropyrrolo[3,4-b]indolizin-3-one. J. Am. Chem. Soc. 2011, 133, 6642-6649. [CrossRef] [PubMed]

8. Kim, E.; Koh, M.; Ryu, J.; Park, S.B. Combinatorial discovery of full-color-tunable emissive fluorescent probes using a single core skeleton, 1,2-dihydropyrrolo[3,4-b]indolizin-3-one. J. Am. Chem. Soc. 2008, 130, 12206-12207. [CrossRef] [PubMed]

9. Kim, E.; Lee, S.; Park, S.B. 9-Aryl-1,2-dihydropyrrolo[3,4-b]indolizin-3-one (Seoul-fluor) as a smart platform for colorful ratiometric fluorescent $\mathrm{pH}$ sensors. Chem. Commun. 2011, 47, 7734-7736. [CrossRef] [PubMed]

10. Kim, E.; Lee, S.; Park, S.B. A Seoul-fluor-based bioprobe for lipid droplets and its application in image-based high throughput screening. Chem. Commun. 2012, 48, 2331-2333. [CrossRef] [PubMed]

11. Lerner, D.A.; Evleth, E.M. Photophysical properties of indolizine and some azaindolizines. Chem. Phys. Lett. 1972, 15, 260-262. [CrossRef]

12. Liu, B.; Wang, Z.-J.; Wu, N.; Li, M.; You, J.; Lan, J. Discovery of a full-color-tunable fluorescent core framework through direct C $\mathrm{H}$ (hetero)arylation of $\mathrm{N}$-heterocycles. Chem. Eur. J. 2012, 18, 1599-1603. [CrossRef] [PubMed]

13. Rotaru, A.V.; Druta, I.; Oeser, T.; Müller, T.J.J. A novel coupling 1,3-dipolar cycloaddition sequence as a three-component approach to highly fluorescent indolizines. Helv. Chim. Acta 2005, 88, 1798-1812. [CrossRef]

14. Becuwe, M.; Landy, D.; Delattre, F.; Cazier, F.; Fourmentin, S. Fluorescent indolizine- $\beta$-cyclodextrin derivatives for the detection of volatile organic compounds. Sensors 2008, 8, 3689-3705. [CrossRef]

15. Lungu, N.C.; Dépret, A.; Delattre, F.; Surpateanu, G.G.; Cazier, F.; Woisel, P.; Shirali, P.; Surpateanu, G. Synthesis of a new fluorinated fluorescent $\beta$-cyclodextrin sensor. J. Fluor. Chem. 2005, 126, 385-388. [CrossRef]

16. Hodgkiss, R.J.; Middleton, R.W.; Parrick, J.; Rami, H.K.; Wardman, P.; Wilson, G.D. Bioreductive fluorescent markers for hypoxic cells: A study of 2-nitroimidazoles with 1-substituents containing fluorescent, bridgehead-nitrogen, bicyclic systems. J. Med. Chem. 1992, 35, 1920-1926. [CrossRef] [PubMed]

17. Bayazit, M.K.; Coleman, K.S. Fluorescent single-walled carbon nanotubes following the 1,3-dipolar cycloaddition of pyridinium ylides. J. Am. Chem. Soc. 2009, 131, 10670-10676. [CrossRef] [PubMed]

18. Wu, X.; Cao, H.; Li, B.; Yin, G. The synthesis and fluorescence quenching properties of well soluble hybrid graphene material covalently functionalized with indolizine. Nanotechnology 2011, 22, 075202. [CrossRef] [PubMed]

19. Kel'in, A.V.; Sromek, A.W.; Gevorgyan, V. A novel Cu-assisted cycloisomerization of alkynyl imines: Efficient synthesis of pyrroles and pyrrole-containing heterocycles. J. Am. Chem. Soc. 2001, 123, 2074-2075. [CrossRef] [PubMed]

20. Hardin, A.R.; Sarpong, R. Electronic effects in the Pt-catalyzed cycloisomerization of propargylic esters: Synthesis of 2,3-disubstituted indolizines as a mechanistic probe. Org. Lett. 2007, 9, 4547-4550. [CrossRef] [PubMed]

21. Chernyak, D.; Gevorgyan, V. Organocopper-mediated two-component $\mathrm{S}(\mathrm{N}) 2^{\prime}$-substitution cascade towards N-fused heterocycles. Chem. Heterocycl. Compd. 2012, 47, 1516-1526. [CrossRef] [PubMed]

22. Liu, R.-R.; Ye, S.-C.; Lu, C.-J.; Xiang, B.; Gao, J.; Jia, Y.-X. Au-catalyzed ring-opening reactions of 2-(1-alkynyl-cyclopropyl) pyridines with nucleophiles. Org. Biomol. Chem. 2015, 13, 4855-4858. [CrossRef] [PubMed] 
23. Liu, R.-R.; Cai, Z.-Y.; Lu, C.-J.; Ye, S.-C.; Xiang, B.; Gao, J.; Jia, Y.-X. Indolizine synthesis via Cu-catalyzed cyclization of 2-(2-enynyl) pyridines with nucleophiles. Org. Chem. Front. 2015, 2, 226-230. [CrossRef]

24. Liu, R.R.; Lu, C.J.; Zhang, M.D.; Gao, J.R.; Jia, Y.X. Palladium-catalyzed three-component cascade reaction: Facial access to densely functionalized indolizines. Chem. Eur. J. 2015, 21, 7057-7060. [CrossRef] [PubMed]

25. Kaloko, J.; Hayford, A. Direct synthesis of monofunctionalized indolizine derivatives bearing alkoxymethyl substituents at C-3 and their benzofused analogues. Org. Lett. 2005, 7, 4305-4308. [CrossRef] [PubMed]

26. Chernyak, D.; Skontos, C.; Gevorgyan, V. Two-component approach toward a fully substituted N-fused pyrrole ring. Org. Lett. 2010, 12, 3242-3245. [CrossRef] [PubMed]

27. Meng, X.; Liao, P.; Liu, J.; Bi, X. Silver-catalyzed cyclization of 2-pyridyl alkynyl carbinols with isocyanides: Divergent synthesis of indolizines and pyrroles. Chem. Commun. 2014, 50, 11837-11839. [CrossRef] [PubMed]

28. Yan, B.; Zhou, Y.; Zhang, H.; Chen, J.; Liu, Y. Highly efficient synthesis of functionalized indolizines and indolizinones by copper-catalyzed cycloisomerizations of propargylic pyridines. J. Org. Chem. 2007, 72, 7783-7786. [CrossRef] [PubMed]

29. Yan, B.; Liu, Y. Gold-catalyzed multicomponent synthesis of aminoindolizines from aldehydes, amines, and alkynes under solvent-free conditions or in water. Org. Lett. 2007, 9, 4323-4326. [CrossRef] [PubMed]

30. Seregin, I.V.; Gevorgyan, V. Gold-catalyzed 1,2-migration of silicon, tin, and germanium en route to C-2 substituted fused pyrrole-containing heterocycles. J. Am. Chem. Soc. 2006, 128, 12050-12051. [CrossRef] [PubMed]

31. Smith, C.R.; Bunnelle, E.M.; Rhodes, A.J.; Sarpong, R. Pt-catalyzed cyclization/1,2-migration for the synthesis of indolizines, pyrrolones, and indolizinones. Org. Lett. 2007, 9, 1169-1171. [CrossRef] [PubMed]

32. Katritzky, A.R.; Qiu, G.; Yang, B.; He, H.-Y. Novel syntheses of indolizines and pyrrolo[2,1-a]isoquinolines via benzotriazole methodology. J. Org. Chem. 1999, 64, 7618-7621. [CrossRef]

33. Elender, K.; Riebel, P.; Weber, A.; Sauer, J.R. 1,3-Dipolar cycloaddition reactions of stable bicyclic and monocyclic azomethine ylides: Kinetic aspects. Tetrahedron 2000, 56, 4261-4265. [CrossRef]

34. Bora, U.; Saikia, A.; Boruah, R.C. A novel microwave-mediated one-pot synthesis of indolizines via a three-component reaction. Org. Lett. 2003, 5, 435-438. [CrossRef] [PubMed]

35. Dinica, R.; Druta, I.; Pettinari, C. The synthesis of substituted 7,7'-bis-indolizines via 1,3-dipolar cycloaddition under microwave irradiation. Synlett 2000, 1013-1015. [CrossRef]

36. Dinica, R.M.; Furdui, B.; Ghinea, I.O.; Bahrim, G.; Bonte, S.; Demeunynck, M. Novel one-pot green synthesis of indolizines biocatalyzed by Candida antartica lipases. Mar. Drugs 2013, 11, 431-439. [CrossRef] [PubMed]

37. Douglass, J.E.; Tabor, M.W.; Spradling, J.E., III. Effect of 4-substituents on the stability of pyridinium dicarbethoxymethylides. J. Heterocycl. Chem. 1972, 9, 53-56. [CrossRef]

38. Georgescu, E.; Caira, M.R.; Georgescu, F.; Draghici, B.; Popa, M.M.; Dumitrascu, F. One-pot, three-component synthesis of a library of new pyrrolo[1,2-a]quinoline derivatives. Synlett 2009, 1795-1799. [CrossRef]

39. Shang, Y.; Zhang, M.; Yu, S.; Ju, K.; He, X. New routes synthesis of indolizines via 1,3-dipolar cycloaddition of pyridiniums and alkynes. Tetrahedron Lett. 2009, 50, 6981-6984. [CrossRef]

40. Huisgen, R. On the mechanism of 1,3-dipolar cycloadditions. A reply. J. Org. Chem. 1968, 33, $2291-2297$. [CrossRef]

41. Matsumoto, K.; Hayashi, N.; Ikemi, Y.; Toda, M.; Uchida, T.; Aoyama, Y.; Miyakoshi, Y. Inverse electron-demand 1,3-dipolar cycloaddition reactions of cyclooctyne with pyridinium bis(methoxycarbonyl) methylides. J. Het. Chem. 2001, 38, 371-377. [CrossRef]

42. Shevchenko, V.V.; Zhegalova, N.G.; Borsenko, A.O.; Nikolaev, A.E. On the most powerful chemical traps for bis(methoxycarbonyl)carbene (2-methoxy-1-(methoxycarbonyl)-2-oxoethylidene). Helv. Chim. Acta 2008, 91, 501-509. [CrossRef]

43. Sustmann, R. A simple model for substituent effects in cycloaddition reactions. II. The diels-alder reaction. Tetrahedron Lett. 1971, 12, 2721-2724. [CrossRef]

44. Sustmann, R. Orbital energy control of cycloaddition reactivity. Pure Appl. Chem. 1974, 40, 569-593. [CrossRef]

45. Sandeep, C.; Padmashali, B.; Kulkarni, R.S. Efficient synthesis of indolizines and new imidazo[1,2-a]pyridines via the expected cyclization of aromatic cycloimmonium ylides with electron deficient alkynes and ethyl cyanoformate. Tetrahedron Lett. 2013, 54, 6411-6414. [CrossRef] 
46. Sandeep, C.; Padmashali, B.; Kulkarni, R.S.; Mallikarjuna, S.M.; Siddesh, M.B.; Nagesh, H.K.; Thriveni, K.S. Synthesis of substituted 5-acetyl-3-benzoylindolizine-1-carboxylate from substituted 2-acetyl pyridinium bromides. Het. Lett. 2014, 4, 371-376.

47. Phillips, W.G.; Ratts, K.W. Basicity of n-ylides. J. Org. Chem. 1970, 35, 3144-3147. [CrossRef]

48. Dega-Szafran, Z.; Schroeder, G.; Szafran, M.; Szwajca, A.; Łeska, B.; Lewandowska, M. Experimental and quantum chemical evidences for $\mathrm{C}-\mathrm{H} \cdots \mathrm{N}$ hydrogen bonds involving quaternary pyridinium salts and pyridinium ylides. J. Mol. Struct. 2000, 555, 31-42. [CrossRef]

49. Zhang, X.M.; Bordwell, F.G.; Van Der Puy, M.; Fried, H.E. Equilibrium acidities and homolytic bond dissociation energies of the acidic carbon-hydrogen bonds in N-substituted trimethylammonium and pyridinium cations. J. Org. Chem. 1993, 58, 3060-3066. [CrossRef]

50. Le Droumaguet, C.; Wang, C.; Wang, Q. Fluorogenic click reaction. Chem. Soc. Rev. 2010, 39, $1233-1239$. [CrossRef] [PubMed]

51. Rotaru, A.; Druta, I.; Avram, E.; Danac, R. Synthesis and properties of fluorescent 1,3-substituted mono and biindolizines. ARKIVOC 2009, xiii, 287-289.

52. Devaraj, N.K.; Weissleder, R. Biomedical applications of tetrazine cycloadditions. Acc. Chem. Res. 2011, 44, 816-827. [CrossRef] [PubMed]

53. Saracoglu, N. Recent advances and applications in 1,2,4,5-tetrazine chemistry. Tetrahedron 2007, 63, 4199-4236. [CrossRef]

54. Bonte, S.; Ghinea, I.O.; Xuereb, J.-P.; Dinica, R.; Demeunynck, M. Playing with lipases to favor 1,2- versus 1,4-addition of nucleophiles to propiolic ester: Access to activated terminal alkines. Tetrahedron 2013, 69, 5499-5500.

55. Austin, W.B.; Bilow, N.; Kelleghan, W.J.; Lau, K.S.Y. Facile synthesis fo ethynylated benzoic acid derivatives and aromatic compounds via ethynyltrimethylsilane. J. Org. Chem. 1981, 46, 4280. [CrossRef]

56. Allgäuer, D.S.; Mayr, H. One-pot two-step synthesis of 1-(ethoxycarbonyl)indolizines via pyridinium ylides. Eur. J. Org. Chem. 2013, 2013, 6379-6388. [CrossRef]

57. Seethalakshmi, T.; Venkatesan, P.; Fronczek, F.R.; Kaliannan, P.; Thamotharan, S. 4-amino-(1-carboxymethyl) pyridinium chloride. Acta Crystallogr. Sect. E Struct. Rep. Online 2006, 62, o3389-o3390. [CrossRef]

58. Gundersen, L.-L.; Charnock, C.; Negussie, A.H.; Rise, F.; Teklu, S. Synthesis of indolizine derivatives with selective antibacterial activity against mycobacterium tuberculosis. Eur. J. Pharm. Sci. 2007, 30, 26-35. [CrossRef] [PubMed]

59. Matsumoto, K.; Fujita, H.; Deguchi, Y. Formation of a novel complex between pyridinium bis(alkoxycarbonyl)methylides and diphenylcyclopropenone; trapping of pyridinium bis(alkoxycarbonyl) methylide cation radicals. J. Chem. Soc. Chem. Commun. 1978, 817-819. [CrossRef]

60. Rečnik, S.; Svete, J.; Stanovnik, B. Ring contractions of 4-oxoquinolizine-3-diazonium tetrafluoroborates, by an aza-Wolff rearrangement, to alkyl indolizine-3-carboxylates. Eur. J. Org. Chem. 2001, 2001, 3705-3709. [CrossRef]

61. Soare, M.-L.; Ungureanu, E.-M.; Georgescu, E.; Birzan, L. Synthesis and electrochemical characterization of substituted indolizine carboxylates. J. Serb. Chem. Soc. 2013, 78, 827-838. [CrossRef]

Sample Availability: Samples of the compounds are not available from the authors.

(C) 2016 by the authors; licensee MDPI, Basel, Switzerland. This article is an open access article distributed under the terms and conditions of the Creative Commons by Attribution (CC-BY) license (http://creativecommons.org/licenses/by/4.0/). 